\title{
High-Resolution Morphobathymetric Analysis and Evolution of Capbreton Submarine Canyon Head (Southeast Bay of Biscay-French Atlantic Coast) over the Last Decade Using Descriptive and Numerical Modeling
}

\author{
Alaïs Mazières ${ }^{a}$, Hervé Gillet ${ }^{a}$, Bruno Castelle ${ }^{a}$, Thierry Mulder ${ }^{a}$, Corenthin Guyot ${ }^{b}$, Thierry Garlan ${ }^{c}$, \\ Cyril Mallet ${ }^{\mathrm{d}}$
}

\footnotetext{
a Université de Bordeaux, UMR 5805 EPOC, Allée Geoffroy Saint-Hilaire, 33615 Pessac cedex, France.

${ }^{\mathrm{b}}$ IFREMER, Centre de Brest, Plouzané, France.

c SHOM, Service Hydrographique et Océanographique de la Marine, 13 rue du Chatellier, 29200 Brest, France

' BRGM Aquitaine, Parc Technologique Europarc, 24 avenue Léonard de Vinci, Pessac 33600, France.
}

Corresponding author : Alaïs Mazières, email address : alais.mazieres@u-bordeaux1.fr

\begin{abstract}
:
In this study, the Capbreton canyon head, just off the coast, is investigated using high-resolution multibeam bathymetry datasets, sediment samples and numerical modeling. The HR bathymetry analysis reveals a morphological connection between the longshore trough and the head of the canyon. The analysis of recent sediment samples shows a clear correlation between the sediment of the canyon head and that of the nearshore. Hydrodynamic modeling (a coupled wave-flow model) shows that for high-energy waves, the rotational nature of surf-zone circulation reverses and waveinduced currents have the potential to transport large quantities of nearshore sands toward the canyon head. All these arguments support the assumption that the canyon head captures a part of the sand transported by longshore drift. Over the 15 years of observation (1998-2013), time-lapse bathymetry shows that the floor of the canyon head and one lateral gully network experienced significant morphological reworking. In terms of hazards, despite this strong activity, the position of the canyon head and the profile of its longitudinal slope remained stable and appears as a comforting factor. However, the activity of unusual lateral erosions needs to be monitored.
\end{abstract}

\section{Highlights}

The canyon head acts as a sediment buffer that traps part of the longshore drift sediments. The canyon head experienced significant morphologic evolution over the past 14 years. However, the general shape and position of the canyon head has remained stable.

Keywords : longshore drift ; submarine canyon ; Capbreton ; hydrodynamic modeling ; sediment transport 


\section{Introduction}

Submarine canyons have been studied in many different environments throughout the world (e.g. Shepard, 1981). These studies have demonstrated that active processes remain functional during highstands and that canyons are preferential pathways for the shelf to slope transfer of terrigenous sediment (Durrieu de Madron, 1994; Mullenbach and Nittrouer, 2000; Shepard, 1981; and Shepard and Dill, 1966). Canyons close to the coast can also trap longshore drift sediment (Canals et al., 2006; Lastras et al., 2007; and Lewis and Barnes, 1999).

Canyon heads have only recently become the subject of high-resolution mapping, mainly due to the difficulty in collecting large-scale, high-quality data (due to irregular topography and shallow water). Over the past few decades, bathymetric surveys have became an essential tool for describing and understanding this sedimentary environment and its relationship with the coast (e.g. Mullenbach et al., 2004; Paull et al., 2011; Smith et al., 2007; and Yoshikawa and Nemoto, 2010). Obtaining accurate and detailed bathymetric maps is essential for documenting the morphology of the seafloor, understanding the sedimentary processes within submarine canyons and to assess the relevance of coastal geological hazards.

The present paper focuses on Capbreton canyon head, and is based on multibeam bathymetry datasets, sediment samples and numerical modeling. First, the study site is described, as well as the methodology and data (section 2). In section 3, a descriptive and comparative analysis is provided of the geophysical and sedimentological datasets and the hydrodynamic modeling. The aims of our study were to evaluate, first, according to our descriptive and modeling results, the interaction between the Capbreton canyon head and the littoral dynamic cell, and second, based on decade evolution map, the hazard implied by the proximity of the coast (both discussed in section 4).

\section{Setting}

\subsection{Morphological and geological setting}

Capbreton Canyon is located in the southeast of the Bay of Biscay (SW France, Fig.1) and deeply incises the Aquitaine continental slope and shelf. It is a 300-kilometer-long meandering submarine structure that runs parallel with the north coast of Spain, before curving northwards and disappearing down the continental slope at a depth of 3,500 meters 
below sea level (Cirac et al., 2001; Cremer, 1983; and Gaudin et al., 2006). The "downcutting" of Capbreton Canyon first began in the Paleogene, in a zone of tectonic weakness generated by the convergence of the Iberian and European plates (Deregnaucourt and Boillot, 1982). Several studies have demonstrated the prevailing impact of deep-rooted tectonic structures on the localization and overall morphology of Capbreton Canyon (Bois et al., 1997; Cirac et al., 2001; and Deregnaucourt and Boillot, 1982). Since that time, the canyon has been shaped by differential sedimentation (a confined channel-levee system) as opposed to long-term erosion (Cremer et al., 2012). The canyon head, which is the focus of this study, ranges from a depth of 10 to 100 meters below sealevel. Located only 250 meters off the coastline, it forms a deep and wide amphitheatre that faces out to sea (Froidefond, 1982; and Gaudin et al., 2006) (Fig. 1).

\subsection{Hydrodynamic setting}

Capbreton Canyon is currently active. Its hydrodynamics are dominated by two types of current: (1) internal waves generating the particle-laden upstream or downstream motion of wave masses along the seafloor (Mulder et al., 2012; and Pingree et al., 1986) and (2) low to high energy turbidity currents (mean velocity $=0.2-0.3$ and $1-3 \mathrm{~m} / \mathrm{s}$, resp.), which regularly transfer fine to coarse particles toward the deep sea (Mulder et al., 2012). Recent turbidites have been identified in deep areas ( $250 \mathrm{~m}$ to $700 \mathrm{~m}$ below sealevel) of the canyon (Gaudin et al., 2006; and Nesteroff et al., 1968). A turbidite deposited by a turbulent surge generated during the Martin storm (December 27, 1999) has been recovered in an interface core (Mulder et al., 2001). Moreover, the analysis of recently collected Kullenberg cores has shown that the canyon has experienced approximately one turbidity current per year over the last century (Brocheray et al., 2014).

The Aquitaine coast is exposed to high energy North Atlantic swells traveling mainly from the W-NW sector (Butel et al., 2002), generating a strong southward longshore drift and an annual average of approximately $38,000 \mathrm{~m}^{3}$ to $657,000 \mathrm{~m}^{3}$ of transported sediment along the Aquitaine coast (Idier et al., 2013). This figure decreases dramatically in the vicinity of the canyon head: it is estimated at approximately $40,000 \mathrm{~m}^{3} /$ year just north of the canyon and only $1000 \mathrm{~m}^{3} /$ year to the south (Abadie et al., 2006).

\subsection{Sediment supply}


Capbreton Canyon has been in close relationship with the Adour river throughout its geological history, and successive connections and disconnections have been evidenced during the Quaternary (Klingebiel and Legigan, 1978). However, the canyon head was naturally disconnected from the Adour river in $1310 \mathrm{AD}$, and in 1578 the Adour river mouth was artificially relocated 15 kilometers south of the canyon head, preventing reconnection (Klingebiel and Legigan, 1978).

Although the canyon is currently disconnected from the Adour river, the river probably continues to play a role in the delivery of sediment to the canyon. In fact, a recent study based on satellite remote sensing images has revealed that over the course of a year, the plume of Adour river $\left(0.25 \times 10^{6} \mathrm{t} / \mathrm{yr}\right.$. of suspended sediment exported to the ocean) reaches the canyon head $20 \%$ of the time (Petus, 2009), as the easterly winds tend to push the plume in a northward direction.

The former Adour river mouth is currently a small coastal river mouth, known as the "Boucarot." This channel connects the ocean to Hossegor lake (a $1 \mathrm{~km}^{2}$ coastal lake enclosed at the back by an eolian dune system), working as a tidal pass rather than an estuary. Current sediment output from the channel is insignificant. To secure access to Capbreton marina, two training walls were constructed in the 1970s. Not surprisingly, this resulted in the updrift accretion and downdrift erosion of the nearby beaches. Since 2008, this trend has been partially balanced by the introduction of a sediment bypass system. The system transfers approximately $100,000 \mathrm{~m}^{3}$ of sediment per year from the north to the south of Boucarot channel (see Fig. 1). This suggests an overall southward longshore drift along the beaches of Hossegor and Capbreton.

Previous studies focusing on the interaction between the head of Capbreton Canyon and the littoral dynamic cell had led to the following scientific debate: (1) hydrodynamic evidence (wave refraction) and in-situ measurements (radioactive tracers) had both suggested that the canyon head plays the role of a hydrodynamic barrier preventing the littoral drift from feeding the canyon (Abe, 1984; Duplantier, 1976; and Froidefond, 1982) and (2) the assumed presence of slide scars within the canyon head had suggested that this structure traps the sand supplied by the littoral drift and that the regular destabilization of this stock feeds the turbidity current activity in the canyon (Bourillet et al., 2007; Gaudin et al., 2006; and Mulder et al., 2001). The aim of our study is to provide new evidence toward this debate based on new morphological, sedimentary, and hydrodynamic data.

\section{Methodology and data}




\subsection{Bathymetric surveys}

Eight oceanographic surveys were carried out in the spring and summers of 1998 to 2013 in the upper part of Capbreton Canyon (Table 1). The best bathymetric map published to date in this area was limited to a 20-meter resolution (Bourillet et al., 2007). Our work significantly improves upon this resolution with bathymetric data ranging from a 5 to 0.5 meter horizontal resolution and from $0.2 \%$ to $0.5 \%$ water depth vertical resolution. The bathymetric data were collected and post-processed using IFREMER's CARAIBES ${ }^{\text {TM }}$ software, including manual editing and automated filters, which allowed for the creation of a final digital elevation model (DEM). To perform volume calculation, we used ArcMap (ArcGIS software), using the 3D analysis "surface-volume" tool. Sedimentological analyses were performed by the sedimentology laboratory at Bordeaux 1 University, including grain size measurement (sieving and measurements using a Malvern Mastersizer, which measures particle sizes using laser diffraction). The Wentworth grain size nomenclature has been used in this paper (Wentworth, 1922).

\subsection{Numerical modeling}

A modeling approach was used to address the ability of nearshore wave-driven currents to expel nearshore sediments toward the canyon head. We used the nonlinear morphodynamic model detailed by Castelle and Ruessink (2011). The model couples the spectral model SWAN (Booij et al., 1999) and a short-wave averaged and depth-integrated flow model. Hydrodynamics were then used to drive a model for short-wave averaged sediment transport and bottom changes. The model was validated using field data collected in the surf zone (e.g., Castelle et al., 2006) and was extensively used to address surf-zone sandbar morphodynamics (e.g., Castelle and Coco, 2012). In the current study, we switched off all bottom changes and used only the short-wave averaged sediment transport fluxes. The grid extended 2 kilometers across-shore and 4 kilometers alongshore, with a regular 40-meter grid spacing in both directions. Representative wave conditions (a total of 12) were applied at the boundaries using the classification system set out by Butel et al. (2002). Each class was defined by a significant wave height (Hs), a peak wave period (Tp) and an angle of incidence $(\theta)$. For each wave condition, a low-, mid- or high-tide level was applied to address the influence of both tidal 
elevation and wave conditions on nearshore wave-driven circulation in the vicinity of the canyon head.

\section{Results}

\subsection{High resolution morphological description}

The canyon forms a deep and wide amphitheater facing out to sea. This amphitheater is 1,200 meters wide in its shallower part (the headwall), and decreases to a width of 280 meters as the canyon narrows. The slope of the surrounding inner shelf does not exceed $0.5^{\circ}$. At the head of the canyon, the longitudinal slope increases strongly with a $4^{\circ}$ average over the first kilometer. The slope reaches up to $8^{\circ}$ in the first 100 meters just below the headwall (Fig. 2 and 3).

The two flanks of the canyon head are asymmetrical and can be described as follows: (1) the northern flank is relatively steep, with slopes averaging $12^{\circ}$ to $25^{\circ}$. It is dissected by three small gullies, which are approximately 60 meters wide, and (2) the southern flank is gentler with slopes averaging $5^{\circ}$ to $10^{\circ}$, although they can reach up to $40^{\circ}$ for a few dozen meters here. The southern flank is seriously downcut by a large network of northward gullies (Fig. 2 and 3). This network is 600 meters wide with an incision of up to 50 meters deep. The axial thalweg is 70 meters wide with a longitudinal slope averaging $5^{\circ}$. The proximal headwall is relatively straight. High-resolution bathymetric data (Fig. 2) reveals that the north-eastern headwall of the head is morphologically connected to the shallow 100-meter-wide longshore trough (off Hossegor beach). Similarly, the south-eastern headwall is connected to a shallow cross-shore trough, 200 meters south of the mouth of Boudigau river.

North of the canyon, the inner shelf is characterized by a longshore sandbar located approximately 350 meters from the shoreline ( 5 meters below sealevel). This sandbar is approximately 200 meters wide and 4 meters high. It has a steep slope of $3.15^{\circ}$ facing the coast and a gentle seaward slope of $1.15^{\circ}$ (Fig. 2 and 3).

The headwall is characterized by a succession of shallow cross-shore bedforms that could be interpreted either as submarine sand dunes or as small cross-shore troughs (Fig. 2). These bedforms are approximately 30 to 50 centimeters high and have long-shore wavelengths of 40 to 70 meters; they reach 200 meters in cross-shore length. 
The floor of the canyon head is characterized by high and low amplitude morphological features (Fig. 2). Among the high amplitude morphological features, is a set of three longitudinal residual rocky topographic highs. The tallest is 20 meters above the surrounding seafloor. A sedimentary bench, 450 meters long and 100 meters wide, leans on the northern flank of the canyon head. It is elevated 15 meters above the seafloor at the canyon head. The top of this bench is characterized by a downward dip $\left(<6^{\circ}\right)$ and by transversal sub-linear bedforms.

Several longitudinal channels are found on the canyon floor (Fig. 2). All these channels converge and meet as the canyon narrows. These hectometer-wide channels are about 2 to 10 meters deeper than the surrounding seabed and may act as conduits for downslope sediment transport.

Analysis of the 2012 high-resolution bathymetric data reveals several small undulating morphological features dispersed across the floor of the canyon head. These are transversal sub-linear bedforms, with wavelengths ranging from 30 to 50 meters and an amplitude of 2 to 8 meters. Wavelength increases with depth. These linear bedforms vary in their characteristics, many of them being concave in form at their intersection with longitudinal channels described above.

\subsection{Superficial grain size analysis}

Fig. 4 shows the distribution of seafloor sediment, based on the results of a grain size analysis of Berthois and Shipek grab samples and Kullenberg cores. Down to 6 meters in depth, surface sediment involves coarse- to very coarse-grained sand with a variable amount of gravel (between 1\% and 28\%) and shell fragments. Sediment becomes finer, from coarse sand to muddy sand, from the foreshore to the inner shelf and within the canyon head. Muddy deposits are confined to the canyon head and the northern and southern walls of the canyon. Most of the fine to medium sands are relatively uniform (with median diameters of about 200-250 $\mu \mathrm{m}$ ) compared to the coarser sands, which are more heterogeneous (Fig. 5-A). This analysis of recent sediment samples shows a similar grain size between the canyon-head sediment, the nearshore sandbar and the longshore-trough sediment (composed of fine to medium sands) (Fig. 5-B). In addition, some samples show the sporadic presence of clay and silt mixed with organic matter in the head of the canyon and along the northern canyon wall. 


\subsection{Decennial morphological evolution}

To establish the evolution of the morphology of the canyon head over the past 15 years, we performed four DEM subtractions (1998-2001, 2001-2010, 2010-2012, and 2012-2013). In the following "difference" maps, we restricted the analysis (and representation) to pixels indicating 1 meter or more of erosion or deposition (due to the fact that bathymetric comparison is difficult and involves an assessment of numerous potential sources of error).

The first map illustrating the bathymetric changes between 1998 and 2001 (Fig. 6-A) shows the evolution of the relationship between the canyon head and the uppermost part of the canyon. Over this three-year period, the canyon floor significantly evolved. The most pronounced area of erosion (max. -12 meters) was located below the 120-meter isobath (Fig. 6-A; zone 1). North of this area of maximum erosion is the "Zone 2" area, where two lobeshaped structures ( 7 to 9 meters thick) suggest that sediment was transported from the canyon head.

The map illustrating the bathymetric changes between 2001 and 2010 (Fig. 6-B) shows the most significant morphological evolution of the canyon head. It also represents the longest period of observation. First, we observed the filling of the previously eroded "Zone 1" (6 to 16 meters of maximum vertical sediment accumulation). Conversely, the two deposited lobes of "Zone 2" were seriously eroded (maximum erosion $=8 \mathrm{~m}$, representing a cumulated volume of $560,000 \mathrm{~m}^{3}$ ). The floor of the canyon head appears to have been significantly reworked. The upper part of the canyon head (10 to 70 meters below sea level) mainly experienced a thin deposition (2 to 6 meters thick) and the longitudinal channels (Fig. 6) low levels of erosion (incisions ranging from 3 to 5 meters), stronger in the north than in the south. On the northern flank of the canyon head, the eastern gully was subject to erosion ( -1 to -2 meters), whereas the western gully experienced limited deposition ( 2 to 5 meters). The southern flank of the canyon head was affected by a large amount of erosion leading to the downcutting of a north-facing gully network (Fig. 6-B). The erosion reached 27 meters locally. The total excavated volume was $2,440,000 \mathrm{~m}^{3}$. To the east of these gullies, the southern flank showed lower levels of erosion $\left(600,000 \mathrm{~m}^{3}\right)$. 
The map illustrating the bathymetric changes between 2010 and 2012 (Fig. 6-C) confirms that the canyon head is subject to rapid morphological evolution. "Zone 2" was once again subject to deposition $\left(614,000 \mathrm{~m}^{3}\right)$. Over these two years, most of the canyon head showed a "relatively" thin layer of sediment accumulation (accumulated thickness ranging from 2 to 7 meters), and the gully network that had previously formed on the southern flank began to gently fill $\left(163,000 \mathrm{~m}^{3}\right)$. Areas of erosion were limited to the northern longitudinal channel (2 to 3 meters maximum depth of erosion) and to small scattered areas of erosion on the upper part of the head (from 20 to 70 meters below sealevel). The proximal northeastern headwall of the canyon head showed the shallowest area of erosion in the study. Its morphology and position (along the headwall) lead us to interpret this erosion as a sand slide. It started at 10 meters below sealevel, 430 meters off the coastline and corresponded to a destabilization of $26,000 \mathrm{~m}^{3}$.

The last map illustrates the bathymetric changes between 2012 and 2013 (Fig. 6-D). It represents the shortest period of observation (14 months). We observed the filling of "Zone 3" (6 meters of maximum vertical sediment accumulation), representing a cumulated volume of $440,000 \mathrm{~m}^{3}$. Conversely, the accumulation of "Zone 2" was seriously eroded (maximum erosion $=12$ meters, representing a cumulated volume of $540,000 \mathrm{~m}^{3}$ ). The upper part of the canyon head (10 to 70 meters below sealevel) experienced some thin deposition but above all a lengthening or enlargement of the longitudinal channels that were already present, but less developed, between 2010 and 2012. The proximal northeastern headwall of the canyon head still experienced a small landslide. The end of the erosion of the southern gully network already evidenced over the period of 2010-2012 was again observed during this time, with neither erosion nor significant deposition.

To summarize, between 1998 and 2013, the seafloor of the canyon head was significantly reworked by successive channelized erosion followed by phases of refilling. The proximal part of the canyon head (10 to $70 \mathrm{~m}$ below sealevel) mainly experienced low levels of deposition balanced by dispersed areas of erosion. We must, however, underline that whereas the seafloor showed a rapid and significant evolution, the general morphology and longitudinal and transversal positions of the canyon head remained stable relative to the coast over the 15-year period. Moreover, Figure 7 clearly demonstrates that the longitudinal profile of the canyon head seafloor fluctuated around a stable position of equilibrium. In contrast to this relatively balanced general evolution, the southern flank of the head experienced 
unexpected and intense erosion over the period of 2001-2010 leading to the downcutting of a deep network of gullies and the erosion of $2,440,000 \mathrm{~m}^{3}$ of sediment. Since 2010 , the erosion has come to an end and the gully network has been gradually filling $\left(163,000 \mathrm{~m}^{3}\right)$.

\subsection{Numerical modeling}

Overall, the simulations showed two contrasting wave-driven circulation patterns (Fig. 8). For low to moderate energy wave conditions (wave class 4 (Butel et al., 2002), $\mathrm{Hs}=1.23 \mathrm{~m}, \mathrm{Tp}=$ $12.53 \mathrm{~s}$, and $\theta=20.29^{\circ}$ ), wave refraction over the canyon resulted in wave energy focusing on the northern beaches of Hossegor ( $y \approx 2500 \mathrm{~m}$ in Fig. 8a). Weak to non-breaking waves across the nearshore sandbar together with a breaking wave angle slightly oriented northward generated a weak northerly longshore current. In these situations (left-hand panels in Fig. 8), it can be argued that nearshore sands (D50: $200 \mu \mathrm{m}$ ) could not reach the canyon head as wave-driven mean currents in the vicinity of the canyon head were mostly directed onshore and were weaker than $0.1 \mathrm{~m} / \mathrm{s}$. This contrasted with the situation with high-energy waves (wave class 8 (Butel et al., 2002) with $\mathrm{Hs}=2.51 \mathrm{~m}, \mathrm{Tp}=7.7 \mathrm{~s}$, and $\theta=23.05^{\circ}$; right-hand panels in Fig. 8). Intense, depth-induced wave-breaking dissipation was observed across the nearshore sandbar, while non-breaking waves were observed over the canyon immediately to the south. This alongshore differential broken-wave energy dissipation was the driving mechanism for flow vorticity (Bonneton et al., 2010; and Bruneau et al., 2011). This drove an intense southeast current (up to $1.5 \mathrm{~m} / \mathrm{s}$ ) into the canyon head. In this situation, substantial quantities of beach sands could be transported into the canyon head. This is further illustrated in Fig. 9. In addition, our simulations have shown that, not surprisingly, the former situation is favored by high water levels, while the latter is favored by low water levels. Our simulations have shown that offshore wave angle does not significantly impact nearshore circulation in the Capbreton area. This surprisingly low influence of wave angle is due to (1) the exposure of the area to ocean waves at a reasonably narrow range of angle of incidence, that is, $10^{\circ}<\theta$ $<23^{\circ}$ (Abadie et al., 2006) and (2) the canyon which, through offshore wave refraction, forces inshore wave energy to focus in areas that constrain the local breaking wave angle. Essentially, wave height and tidal level were found to dictate circulation patterns. The influence of wave period was also significant as wave focusing increased with increasing incident wave period.

\section{Discussion}




\subsection{Sedimentary processes in the canyon head}

The morphological analysis has shown that both the longshore subtidal sandbar and the associated longshore trough connect with the northeastern edge of the canyon head (Fig. 2). In addition, sediment samples from the canyon head are similar to the samples collected along the surrounding seabed. In particular, there is a good fit between the fine to medium detritic sands of the canyon head and the sands of the surrounding upper shoreface (including the sand of the subtidal sandbar and trough, Fig. 4 and 5).

Finally, our wave-driven current simulations (Fig. 8 and 9) have produced the following two key results: for high-energy wave conditions (1) the wave-driven currents are especially active over the subtidal sandbar and outer trough area and (2) an intense southward longshore current reaches the north-eastern edge of the canyon head (current vectors converge into this part of the canyon head; Fig. 8). Considering the velocity of this current (1.5 m/s), the D50 grain size of the upper shoreface sediment $(200 \mu \mathrm{m})$, and the nonlinear morphodynamic model, we suggest that such high-energy wave conditions lead to the transportation of large quantities of sands from the upper shoreface toward the proximal part of the canyon head. All this evidence clearly supports the hitherto poorly-argued assumption that the southward longshore drift acting along the Aquitaine coast contributes to the sediment load of Capbreton canyon head. We have demonstrated, however, that this occurs only under high-energy wave conditions (wave class 8 (Butel et al., 2002) with $\mathrm{Hs}=2.51 \mathrm{~m}, \mathrm{Tp}=7.7 \mathrm{~s}$ and $\theta=23.05^{\circ}$, i.e. $6 \%$ of the year). Moreover, we have observed that a significant portion of this sediment did not seem to get trapped in the canyon head but continued its way southward along the coast. This is supported by (1) modeling (Fig. 8 and 9) and (2) the interpretation of the morphology of the beaches on both sides of Capbreton jetty: strong accumulation to the north vs. starved beach to the south, with the implementation of a sediment bypass system (Fig. 1.). Further studies are needed, however, to identify the amount of sediment entering the canyon head, for example by installing sediment traps. Similar examples of large amounts of sediment entering a canyon head have been demonstrated in other canyons around the world. For example, more than 200,000 $\mathrm{m}^{3} /$ year of littoral sand and gravel enter Monterey canyon head (Eittreim et al., 2002; Smith et al., 2007; and Smith et al., 2005), and 50,000 $\mathrm{m}^{3} /$ year enter Komagoe submarine canyon (Yoshikawa and Nemoto, 2010). In addition, the analysis of new sediment samples has shown the presence of clay mixed with organic matter in the head of the canyon (36\% of the samples showed traces of MO-rich clay). 
The large Adour river plume is present for $20 \%$ of the year, extending 15 kilometers out to sea from the town of Capbreton, with a maximum concentration of $15 \mathrm{mg}$. 1-1 (Petus, 2009; and Petus et al., 2014). Studies of shelf sediment cover have revealed that there is no clay accumulation in the close vicinity of the canyon head (Allen and Castaing, 1977; and Augris et al., 2009). The nearest shelf clay patch lies on the Basque narrow shelf, 40 kilometers southwest of our canyon head (Jouanneau et al., 2008). According to these arguments, the Adour plume appears to be a potential source of MO-rich clay in the area. Such a relationship has already been observed during flooding periods between the Eel river mouth and the Eel canyon head (located 10 kilometers out to sea from the river mouth) (Mullenbach and Nittrouer, 2000; and Mullenbach et al., 2004). Moreover, previous studies have shown that suspended sediments can be preferentially trapped in canyon systems (Baker and Hickey, 1986; and Puig and Palanques, 1998).

The analysis of decennial morphological evolution has shown a relatively uniform accretion on the upper part of the head. Erosion appears more focused with an extension and enlargement of the longitudinal channels or the erosion of the gully networks. These longitudinal channels meet at the canyon narrows suggesting the evacuation of sediment downward into the canyon. To summarize, the head of Capbreton Canyon acts as a sediment buffer, with 1) temporal sediment trapping phases and 2) an evacuation of the sediment into the canyon. Our 15-year study has shown a strong and rapid morphobathymetric evolution of the canyon floor, however the global morphology of the canyon head has remained stable (Fig. 6). This relative stability is supported by the evolution of the longitudinal profile of the canyon head seafloor (Fig. 7), which clearly fluctuates around a stable position of equilibrium. This argument suggests that there is a good balance between inputs (longshore drift) and exports (processes to be determined) in the canyon head.

Between 2001 and 2010, the southern flank of the canyon head was affected by major erosion leading to the downcutting of the northfacing gully network described in Fig. 6. According to past low-resolution bathymetric data (Froidefond et al., 1983; Fig. 11), it appears that this network of gullies was absent in 1860 but already present in 1963. Our study shows that these gullies are almost imperceptible and appear as rough lineament because they were filled in 2001, reappeared in 2010, began to fill again over the period of 2010-2012 and stabilized over the period of 2012-2013. Downcutting of this network of gullies was observed during our longest time-lapse (2001-2010) and we cannot know whether it corresponds to a single 
event arising from a specific storm (Klaus: 23th January 2009 or Xynthia: 27 February 2010) or several associated events.

\subsection{Bedforms}

For several years, bedforms were suspected to be present in the head of Capbreton Canyon because bright and rectilinear transversal structures had been observed on backscatter imagery in the lowermost part of the head (Gaudin et al., 2006). Our HR morphological analysis has clearly revealed transversal sub-linear bedforms located 10 to 100 meters below sealevel, where the channel's thalweg slope averages $8^{\circ}$ to $2^{\circ}$ (Fig. 2 and 3 ). Wavelengths range from 30 to 50 meters and amplitude ranges from 2 to 8 meters.

Comparison (Fig. 10) shows that these bedforms are morphologically similar to the bedforms mapped in Monterey Canyon (Paull et al., 2011; Paull et al., 2010; Smith et al., 2007; Smith et al., 2005; and Xu et al., 2008) or La Jolla Canyon (Paull et al., 2013), where these features are called crescent-shaped bedforms.

Currently, it appears that there is no consensus on the origin of these bedforms. In other canyons (Paull et al., 2013; Paull et al., 2011; and Paull et al., 2010), these features have been attributed to various processes, such as cyclic steps in turbidity currents (Cartigny et al., 2011; and Kostic, 2011) and breaching (Mastbergen and Van Den Berg, 2003; and Van Den Berg et al., 2002). Discussion on the origin of the sediment waves observed in our canyon head demonstrates the limits of our current dataset. There is a clear need for (1) better bathymetric data resolution in space and time to establish whether the observed bedforms show a downslope or an up-slope migration and (2) in-situ current measurements (direction and velocity) to identify potential strong currents in the head of the canyon that could explain the origin of these transversal bedforms.

\subsection{Hazards}

Coastal erosion is a serious worldwide environmental issue in coastal zones. The analysis of the head of the Capbreton Canyon and its short-term morphological evolution demonstrate that the upper part of the canyon and the head are both currently experiencing strong activity leading to rapid morphobathymetric evolution. 
The floors of the upper thalweg and canyon head have both experienced consistent significant morphological reworking: tens of thousands of square meters of erosion and dozens of meterdeep incisions and meter-thick layers of deposition. This intense sedimentary activity has prevented any new submarine installation such as cables lying within the canyon head.

The southern network of gullies appeared between 2001 and 2010 and represents a significant movement of sediment $\left(2,440,000 \mathrm{~m}^{3}\right)$. Fortunately, the direction of this erosion remained parallel to the coast. Nevertheless the proximity of the coast (only 1 kilometer) and the nature of this unpredictable phenomenon imply the need for the supervision of erosion, which represents a possible hazard for the nearby coastal infrastructure (e.g. jetties or beachfront buildings).

The general shape and position of the canyon and its head have remained stable throughout the 15 years of observation. We did not observe lateral migration or offshore migration, as has been the case in other canyons (Biscara et al., 2013). Because the general shape and position of the canyon head appear to have been stable over the past 15 years, we believe that, given the current findings, the evolution of the canyon head does not imply a direct short-term hazard for the coastline or coastal infrastructure. However, as this relative stability seems related to a good balance between inputs (longshore drift) and exports (erosion), the Capbreton canyon head sediment budget should be monitored and any disturbing factors (e.g. new coastal installations such as groynes) should be avoided.

\section{Conclusions}

Our work has generated the following key results:

(1) High-resolution bathymetric data analysis has revealed a direct morphological connection between the sedimentary nearshore conduit (longshore trough) and the proximal part of the head of the canyon.

(2) Analysis of the sediment samples has shown a clear correlation between the sediment in the canyon head and that transported by the southward Aquitaine longshore drift (fine to medium sands).

3) Numerical modeling has shown that for high-energy waves, powerful wave-driven longshore currents have the potential to transport large volumes of sediment eroded from the 
beach toward the canyon head. This suggests that the canyon head acts as a sediment sink and is particularly supplied during periods of intense coastal erosion, i.e., during storms.

4) Morphological analysis and decennial evolution have revealed the presence of active erosional longitudinal channels that meet in the canyon narrows and that suggest a downward evacuation of sediment within the canyon.

All this evidence clearly supports the hitherto poorly-argued assumption that the southward longshore drift acting along the Aquitaine coast contributes, under high-energy wave conditions $\left(\mathrm{Hs}=2.51 \mathrm{~m}, \mathrm{Tp}=7.7 \mathrm{~s}\right.$ and $\left.\theta=23.05^{\circ}\right)$, to the sediment load of Capbreton canyon head. We suggest that the head of Capbreton Canyon acts as a sediment buffer, which temporarily traps fine sands (and some mud) before discharging (a process to be determined) toward the canyon.

5) The general shape and position of the canyon head has remained stable throughout the 15 years of observation. Conversely, the floor of the canyon head has experienced consistent significant morphological reworking. The seabed nonetheless oscillates around a position of equilibrium and appears to be in a state of balance over the long-term. The southern flank of the canyon head has been affected by significant erosion (between 2001 and 2010) leading to the downcutting of the southern network of gullies. Considering the extent of this erosion and its irregular activity over time, it strongly differs from the general trend of evolution observed elsewhere in the canyon head.

In terms of hazards, the stability of the canyon head (no lateral migration or offshore migration) appears to be a comforting factor. However, the activity of lateral erosion, such as the southern gully network highlighted between 2001 and 2010, needs to be monitored.

\section{Acknowledgements}

The captains and crews of the R/V La Thalia and Le Suroit are thanked for their assistance during the ITSAS and SEDYMAQ cruises. Technical staffs of Bordeaux University are warmly thanked. We thank Esther Sumner and an anonymous reviewers for their valuable comments which greatly improved this manuscript. This Ph.D. study is funded by BRGM (Bureau de Recherches Géologiques et Minières) and DGA (Délégation Générale de l'Armement), with additional funding from "Actions Marges"(INSU program). BC acknowledges financial support from project BARBEC (ANR N2010 JCJC 602 01). 


\section{Figures and table captions}

Fig.1: (A,B) Location of the study area in the Bay of Biscay with (C) the detailed bathymetry of Capbreton canyon head with the location of cross-sections $\mathrm{AB}, \mathrm{CD}$, and EF.

Table 1: List of oceanographic surveys conducted between 1998 and 2012.

Fig.2: Capbreton canyon head: interpretation of morphological features based on the most recent high-resolution bathymetric data (1.5 meter resolution—June 2012 and August 2009EM2040 and Geoswath multibeam echo sounder).

Fig.3: Topographic sections derived from the bathymetric maps in Fig. 1.

Fig.4: Capbreton Canyon superficial grain size.

Fig.5: A: Coarse-grained bimodal distribution and fine-grained unimodal distribution; B: Cumulative curves representative of fine/medium sand.

Fig.6: Depth differences calculated through raster subtraction of bathymetric grids. Warm colors show erosion of over 1 meter. Cool colors show areas of deposition of over 1 meter. A: Raster subtraction of bathymetric grids corresponding to August 1998 and May 2001. B: Raster subtraction of bathymetric grids corresponding to May 2001 and June 2010. C: Raster subtraction of bathymetric grids corresponding to June 2010 and June 2012.

Fig. 7: Decennial evolution of the floor of the canyon head (2001-2013). Bathymetric profiles correspond to the profile $\mathrm{AB}$ (located in Fig. 1) but only between 20 and 130 meters below sealevel, where there is a cross referencing of four different years.

Fig.8: $(a, b)$ Simulated wave field with color bars indicating significant wave height, Hs, in meters, and (c, d) resulting wave-driven currents (arrows, every other vector is plotted for readability) with color bars indicating water depth in meters. Left-hand panels: wave class 4 (Butel et al., 2002) with $\mathrm{Hs}=1.23 \mathrm{~m}, \mathrm{Tp}=12.53 \mathrm{~s}$ and $\theta=20.29^{\circ}$ at low tide. Right-hand 
panels: wave class 8 (Butel et al., 2002) with $\mathrm{Hs}=2.51 \mathrm{~m}, \mathrm{Tp}=7.7 \mathrm{~s}$ and $\theta=23.05^{\circ}$ at high tide.

Fig.9: Diagram of wave-driven circulation in the vicinity of the canyon head. (a) Low to moderate energy waves resulting in weak to non-breaking waves across the nearshore sandbar. The combination of wave focusing and wave obliquity at breaking drives a weak northward longshore current. (b) High energy waves resulting in intense depth-induced waves breaking seaward and across the nearshore sandbar with significant wave focusing. This results in intense alongshore broken-wave energy dissipation, $\mathrm{D}$, from which the vectorial product with the unit wave ray vector, $\mathrm{e}_{\mathrm{k}}$, gives a measure of the vorticity forcing term, $\mathrm{F}_{\mathrm{v}}$ (see Bonneton et al., 2010; Bruneau et al., 2011; and Castelle et al., 2012 for more information). This in turn drives an intense longshore current, which is deflected into the canyon head. In panels (a) and (b), LG and LN refer to the internationally famous world-class surf spots "La Gravière" and "La Nord", respectively, which are the result of the wavefocusing patterns at the canyon head.

Fig.10: A and B: Bathymetry of the upper part of Monterey Canyon (Smith et al. 2005) and of Capbreton Canyon, with location of cross sections A', B', C', and D'. C: Profiles of seafloor from the upper floor of Monterey Canyon (modified from Smith et al., 2005 and Cartigny et al., 2011), and a profile from the upper floor of Capbreton Canyon.

Fig.11: Capbreton canyon head over the past two centuries, based on Froidefond (1983) (Bathymetric data compilation from 1860, 1963, May 2001, June 2012 and August 2009).

\section{References}

Abadie, S., Butel, R., Mauriet, S., Morichon, D., Dupuis, H., 2006. Wave climate and longshore drift on the South Aquitaine coast. Continental Shelf Research 26, 1924-1939. Abe, J., 1984. Etude des mouvements sédimentaires dans la zone du canyon de Capbreton à l'aide de traceurs radioactifs et fluorescents (France). These de 3eme cycle, Université de Bordeaux 1 (France), p. 204.

Allen, G., Castaing, P., 1977. Carte de répartition des sédiments superficiels sur le plateau continental du Golfe de Gascogne. Bulletin de l'Institut de Géologie du Bassin d'Aquitaine, 255-260. 
Augris, C., Milly, N.C., de Casamajor, M.-N., 2009. Atlas thématique de l'environnement marin du Pays Basque et du sud des Landes. Editions Quae.

Baker, E.T., Hickey, B.M., 1986. Contemporary sedimentation processes in and around an active West Coast submarine canyon. Marine Geology 71, 15-34.

Biscara, L., Mulder, T., Hanquiez, V., Marieu, V., Crespin, J.-P., Braccini, E., Garlan, T., 2013. Morphological evolution of Cap Lopez Canyon (Gabon): Illustration of lateral migration processes of a submarine canyon. Marine Geology 340, 49-56.

Bois, C., Pinet, B., Gariel, O., 1997. The sedimentary cover along the ECORS Bay of Biscay deep seismic reflection profile. A comparison between the Parentis basin and other European rifts and basins. Société géologique de France, Paris, France.

Bonneton, P., Bruneau, N., Castelle, B., and Marche, F., 2010. Large scale Vorticity generation due to dissipating waves in the surf zone. Discrete and Continuous Dynamical Systems - Series B 13, 729--738.

Booij, N., Ris, R., Holthuijsen, L.H., 1999. A third-generation wave model for coastal regions: 1. Model description and validation. Journal of Geophysical Research: Oceans (1978-2012) 104, 7649-7666.

Bourillet, J.-F., Augris, C., Cirac, P., Mazé, J.-P., Normand, A., Loubrieu, B., Crusson, A., Gaudin, M., Poirier, D., Le Bris, C.S., Simplet, L., 2007. Le canyon de Capbreton : carte bathymétrique - Feuille ouest. Quae éditions.

Brocheray, S., Cremer, M., Zaragosi, S., Schmidt, S., Eynaud, F., Rossignol, L., Gillet, H., 2014. 2000 years of frequent turbidite activity in the Capbreton Canyon (Bay of Biscay). Marine Geology 347, 136-152.

Bruneau, N., Bonneton, P., Castelle, B., Pedreros, R., 2011. Modeling rip current circulations and vorticity in a high-energy mesotidal-macrotidal environment. Journal of Geophysical Research: Oceans 116, C07026.

Butel, R., Dupuis, H., Bonneton, P., 2002. Spatial variability of wave conditions on the French Atlantic coast using in-situ data. Journal of Coastal Research, 96-108.

Canals, M., Puig, P., de Madron, X.D., Heussner, S., Palanques, A., Fabres, J., 2006. Flushing submarine canyons. Nature 444, 354-357.

Cartigny, M.J.B., Postma, G., van den Berg, J.H., Mastbergen, D.R., 2011. A comparative study of sediment waves and cyclic steps based on geometries, internal structures and numerical modeling. Marine Geology 280, 40-56. 
Castelle, B., Bonneton, P., Sénéchal, N., Dupuis, H., Butel, R., Michel, D., 2006. Dynamics of wave-induced currents over an alongshore non-uniform multiple-barred sandy beach on the Aquitanian Coast, France. Continental Shelf Research 26, 113-131.

Castelle, B., Coco, G., 2012. The morphodynamics of rip channels on embayed beaches. Continental Shelf Research 43, 10-23.

Castelle, B., Ruessink, B.G., 2011. Modeling formation and subsequent nonlinear evolution of rip channels: Time-varying versus time-invariant wave forcing. Journal of Geophysical Research: Earth Surface 116, F04008.

Cirac, P., Bourillet, J.-F., Griboulard, R., Normand, A., 2001. Le canyon de Capbreton : nouvelles approches morphostructurales et morphosédimentaires. Premiers résultats de la campagne Itsas. Comptes Rendus de l'Académie des Sciences - Series IIA - Earth and Planetary Science 332, 447-455.

Cremer, M., 1983. Approches sédimentologique et géophysique des accumulations turbiditiques : l'éventail profond du Cap-Ferret (Golfe de Gascogne), la série des Grés d'Annot (Alpes de Haute Provence). Université de Bordeaux 1, p. 413.

Cremer, M., Brocheray, S., Gillet, H., Hanquiez, V., 2012. Capbreton canyon : Evidence of its formation by differential sedimentation., XII International Symposium on Oceanography on the Bay of Biscay, Santander (Spain).

Deregnaucourt, D., Boillot, G., 1982. Nouvelle carte structurale du golfe de Gascogne. C. R. Acad Sci Paris Serie II 294, 219-222.

Duplantier, F., 1976. Etude sedimentologique de la zone cotière et du proche plateau continetal de la region de Capbreton. Paleogeographie et evolution actuelle. These de 3eme cycle, Université de Bordeaux 1 (France), p. 131.

Durrieu de Madron, X., 1994. Hydrography and nepheloid structures in the Grand-Rhône canyon. Continental Shelf Research 14, 457-477.

Eittreim, S.L., Xu, J.P., Noble, M., Edwards, B.D., 2002. Towards a sediment budget for the Santa Cruz shelf. Marine Geology 181, 235-248.

Froidefond, J.-M., Castaing, P., Weber, O., 1983. Evolution morpho-sédimentaire de la tête du canyon de Capbreton d'après les cartes de 1860 et de 1963, utilisation des méthodes informatiques. Bulletin de la Société Géologique de France XXV, 705-714.

Froidefond, J.M., 1982. Processus d'évolution d'un littoral sableux aux cours de l'holocène. Application au domaine aquitain. Présentation d'une méthode de géomorphologie dynamique et quantitative. PhD Thesis. University of Bordeaux 1 (France), p. 271. 
Gaudin, M., Mulder, T., Cirac, P., Berné, S., Imbert, P., 2006. Past and present sedimentary activity in the Capbreton Canyon, southern Bay of Biscay. Geo-Marine Letters 26, 331-345. Idier, D., Castelle, B., Charles, E., and Mallet, C., 2013. Longshore sediment flux hindcast: spatio-temporal variability along the SW Atlantic coast of France. Journal of Coastal Research.

Jouanneau, J.-M., Weber, O., Champilou, N., Cirac, P., Muxika, I., Borja, A., Pascual, A., Rodríguez-Lázaro, J., Donard, O., 2008. Recent sedimentary study of the shelf of the Basque country. Journal of Marine Systems 72, 397-406.

Klingebiel, A., Legigan, P., 1978. Histoire géologique des divagations de 1'Adour., In: Proc Congr IVème Centenaire du Détournement de l'Adour 1578-1978., Bayonne, pp. 23-33. Kostic, S., 2011. Modeling of submarine cyclic steps: Controls on their formation, migration, and architecture. Geosphere 7, 294-304.

Lastras, G., Canals, M., Urgeles, R., Amblas, D., Ivanov, M., Droz, L., Dennielou, B., Fabrés, J., Schoolmeester, T., Akhmetzhanov, A., Orange, D., García-García, A., 2007. A walk down the Cap de Creus canyon, Northwestern Mediterranean Sea: Recent processes inferred from morphology and sediment bedforms. Marine Geology 246, 176-192.

Lewis, K.B., Barnes, P.M., 1999. Kaikoura Canyon, New Zealand: active conduit from nearshore sediment zones to trench-axis channel. Marine Geology 162, 39-69.

Mastbergen, D.R., Van Den Berg, J.H., 2003. Breaching in fine sands and the generation of sustained turbidity currents in submarine canyons. Sedimentology 50, 625-637.

Mulder, T., Zaragosi, S., Garlan, T., Mavel, J., Cremer, M., Sottolichio, A., Sénéchal, N., Schmidt, S., 2012. Present deep-submarine canyons activity in the Bay of Biscay (NE Atlantic). Marine Geology 295-298, 113-127.

Mulder, T.M., Weber, O.W., Anschutz, P.A., Jorissen, F.J., Jouanneau, J.M.J., 2001. A few months-old storm-generated turbidite deposited in the Capbreton Canyon (Bay of Biscay, SW France). Geo-Marine Letters 21, 149-156.

Mullenbach, B.L., Nittrouer, C.A., 2000. Rapid deposition of fluvial sediment in the Eel Canyon, northern California. Continental Shelf Research 20, 2191-2212.

Mullenbach, B.L., Nittrouer, C.A., Puig, P., Orange, D.L., 2004. Sediment deposition in a modern submarine canyon: Eel Canyon, northern California. Marine Geology 211, 101-119. Nesteroff, W., Duplaix, S., Sauvage, J., Lancelot, Y., Melières, F., Vincent, E., 1968. Les dépôts récents du canyon de Capbreton. Bull Soc Géol Fr 7, 218-252. 
Paull, C.K., Caress, D.W., Lundsten, E., Gwiazda, R., Anderson, K., McGann, M., Conrad, J., Edwards, B., Sumner, E.J., 2013. Anatomy of the La Jolla Submarine Canyon system; offshore southern California. Marine Geology 335, 16-34.

Paull, C.K., Caress, D.W., Ussler, W., Lundsten, E., Meiner-Johnson, M., 2011. Highresolution bathymetry of the axial channels within Monterey and Soquel submarine canyons, offshore central California. Geosphere 7, 1077-1101.

Paull, C.K., Ussler III, W., Caress, D.W., Lundsten, E., Covault, J.A., Maier, K.L., Xu, J., Augenstein, S., 2010. Origins of large crescent-shaped bedforms within the axial channel of Monterey Canyon, offshore California. Geosphere 6, 755-774.

Petus, C., 2009. Qualité des eaux cotières du sud du golfe de Gascogne par teledetection spatiale. These de 3eme cycle, Université de Bordeaux 1(France), p. 409.

Petus, C., Marieu, V., Novoa, S., Chust, G., Bruneau, N., Froidefond, J.-M., 2014. Monitoring spatio-temporal variability of the Adour River turbid plume (Bay of Biscay, France) with MODIS 250-m imagery. Continental Shelf Research 74, 35-49.

Pingree, R.D., Mardell, G.T., New, A.L., 1986. Propagation of internal tides from the upper slopes of the Bay of Biscay. Nature 321, 154-158.

Puig, P., Palanques, A., 1998. Nepheloid structure and hydrographic control on the Barcelona continental margin, northwestern Mediterranean. Marine Geology 149, 39-54.

Shepard, F.P., 1981. Submarine canyons; multiple causes and long-time persistence. AAPG Bulletin 65, 1062-1077.

Shepard, F.P., Dill, R.F., 1966. Submarine canyons and other sea valleys. Rand McNally. Smith, D.P., Kvitek, R., Iampietro, P.J., Wong, K., 2007. Twenty-nine months of geomorphic change in upper Monterey Canyon (2002-2005). Marine Geology 236, 79-94.

Smith, D.P., Ruiz, G., Kvitek, R., Iampietro, P.J., 2005. Semiannual patterns of erosion and deposition in upper Monterey Canyon from serial multibeam bathymetry. Geological Society of America Bulletin 117, 1123-1133.

Van Den Berg, J.H., Van Gelder, A., Mastbergen, D.R., 2002. The importance of breaching as a mechanism of subaqueous slope failure in fine sand. Sedimentology 49, 81-95.

Wentworth, C.K., 1922. A Scale of Grade and Class Terms for Clastic Sediments. The Journal of Geology 30, 377-392.

Xu, J.P., Wong, F.L., Kvitek, R., Smith, D.P., Paull, C.K., 2008. Sandwave migration in Monterey Submarine Canyon, Central California. Marine Geology 248, 193-212.

Yoshikawa, S., Nemoto, K., 2010. Seasonal variations of sediment transport to a canyon and coastal erosion along the Shimizu coast, Suruga Bay, Japan. Marine Geology 271, 165-176. 

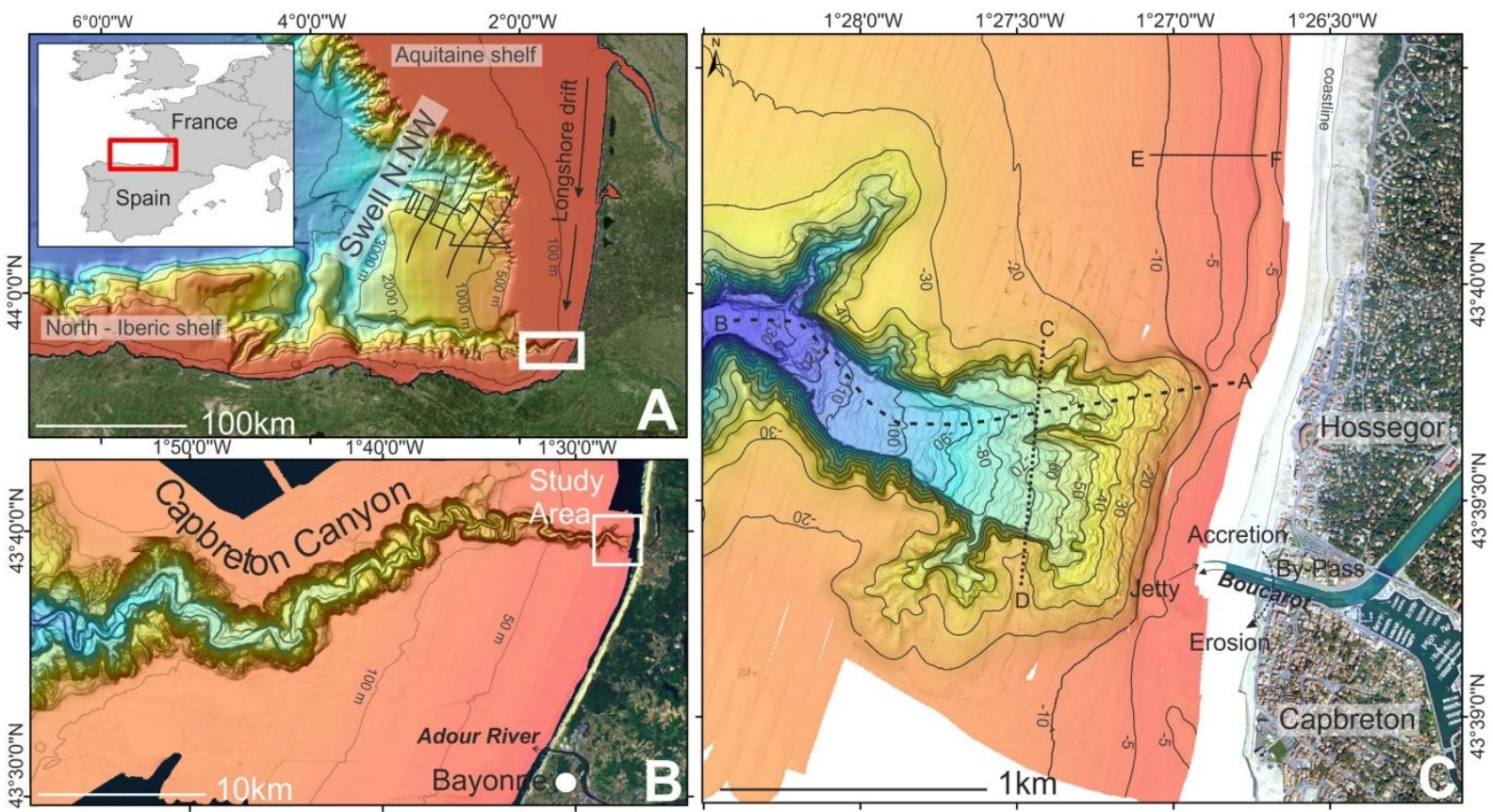

Figure 1 


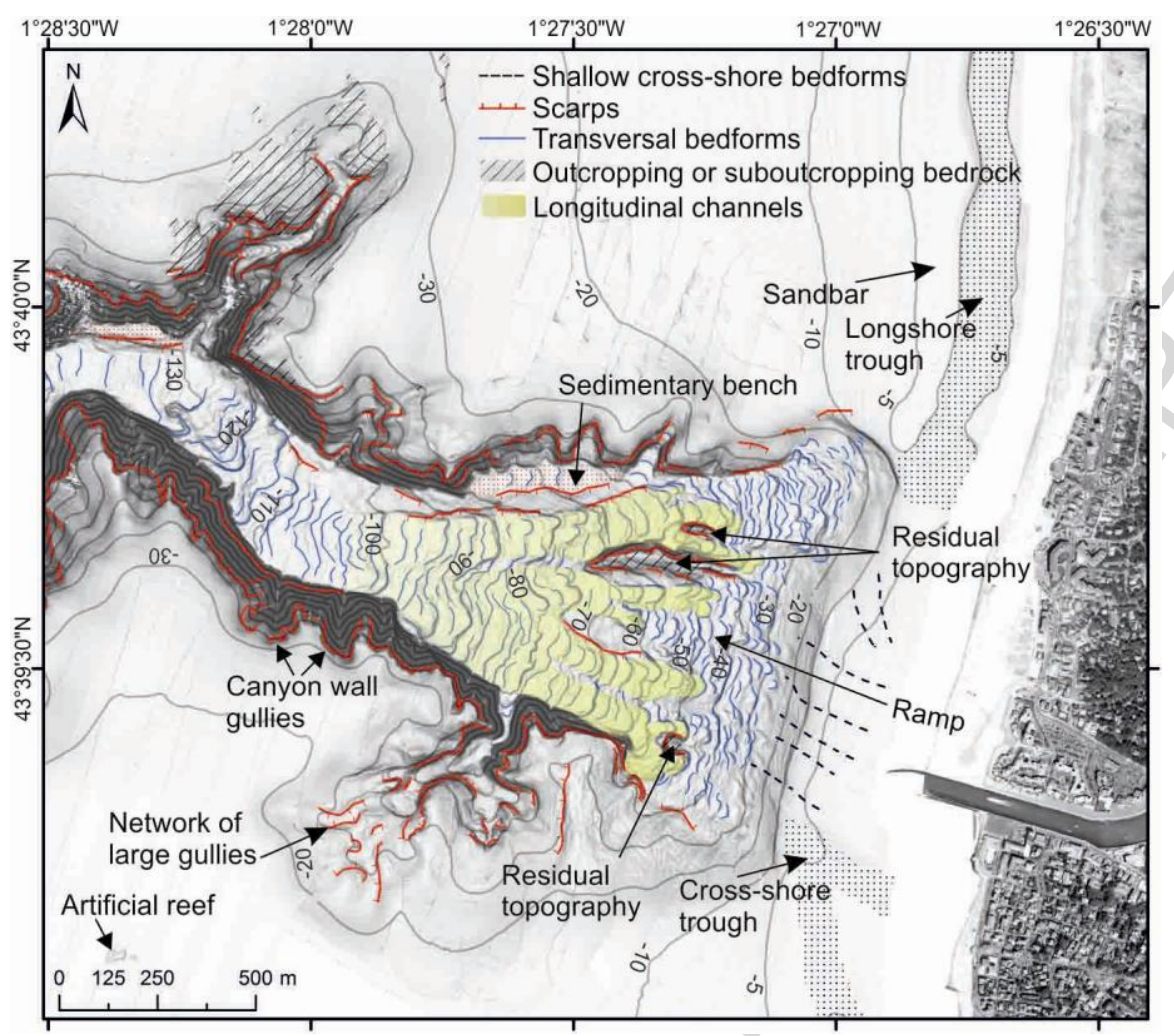

Figure 2 

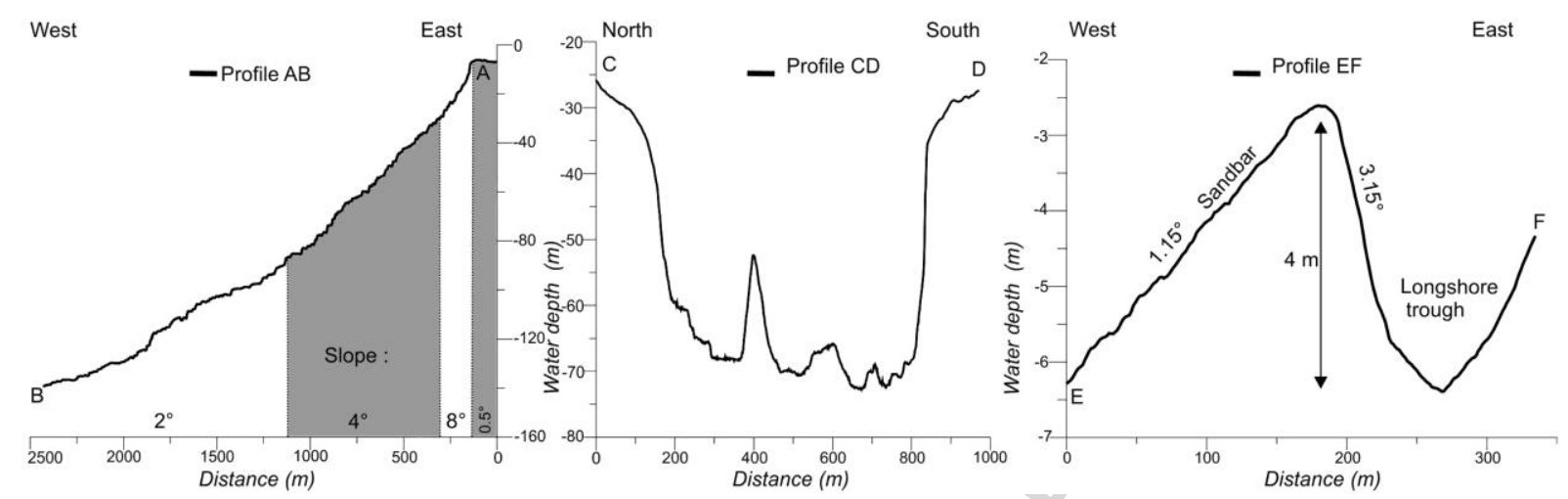

Figure 3 


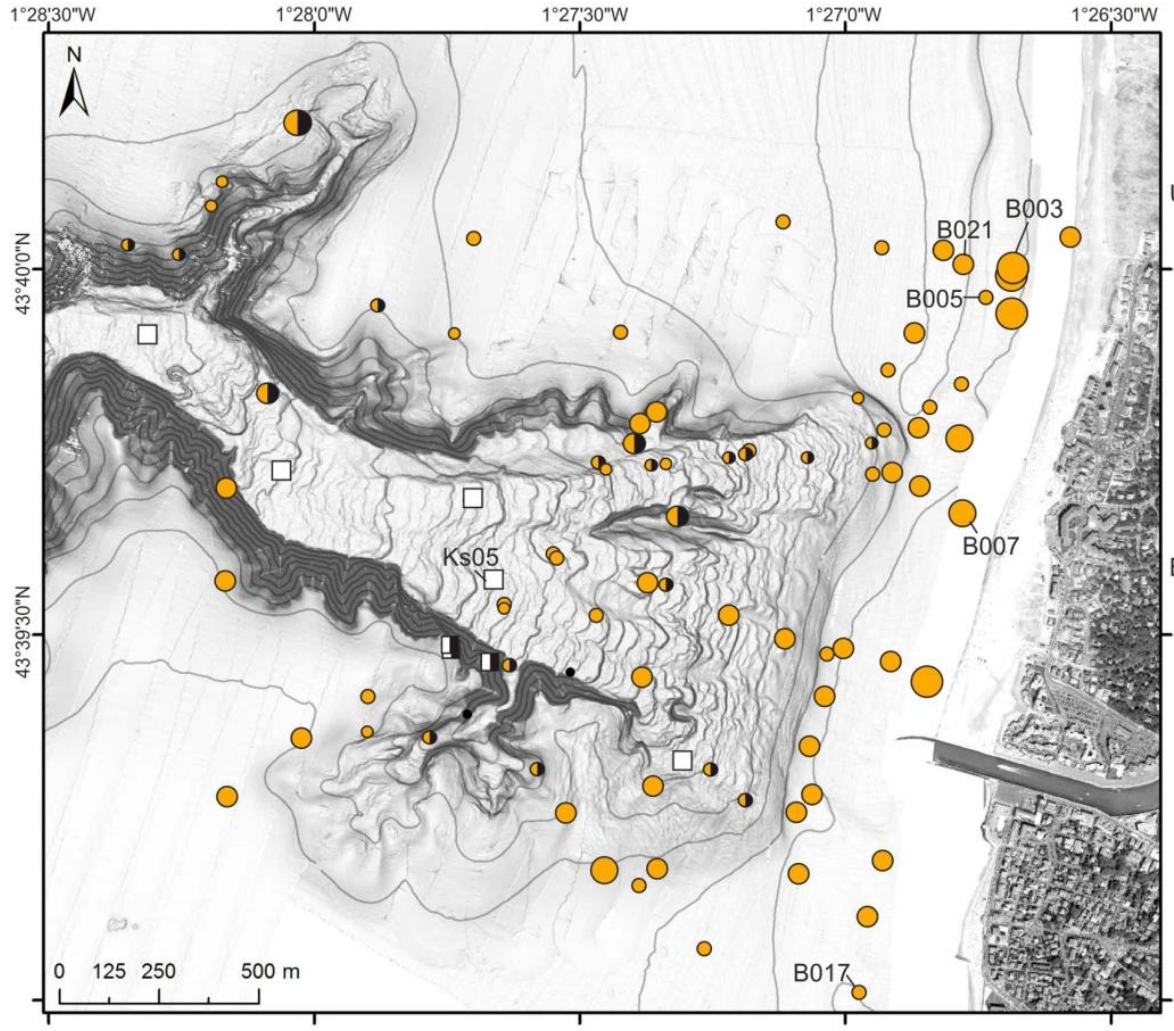

Berthois and Shipek grab Uni-Modal

Very coarse sand

Coarse sand

O Medium sand

- Fine sand

- Very fine sand

- Mud

Bi-Modal

- Coarse sand + Mud

- Medium sand + Mud

- Fine sand + Mud

- Very fine sand + Mud

Kullenberg core

$\square \quad$ Fine sand with sporadic buried muddy layers

- Mud with fine sand and/or organic matter

Figure 4 

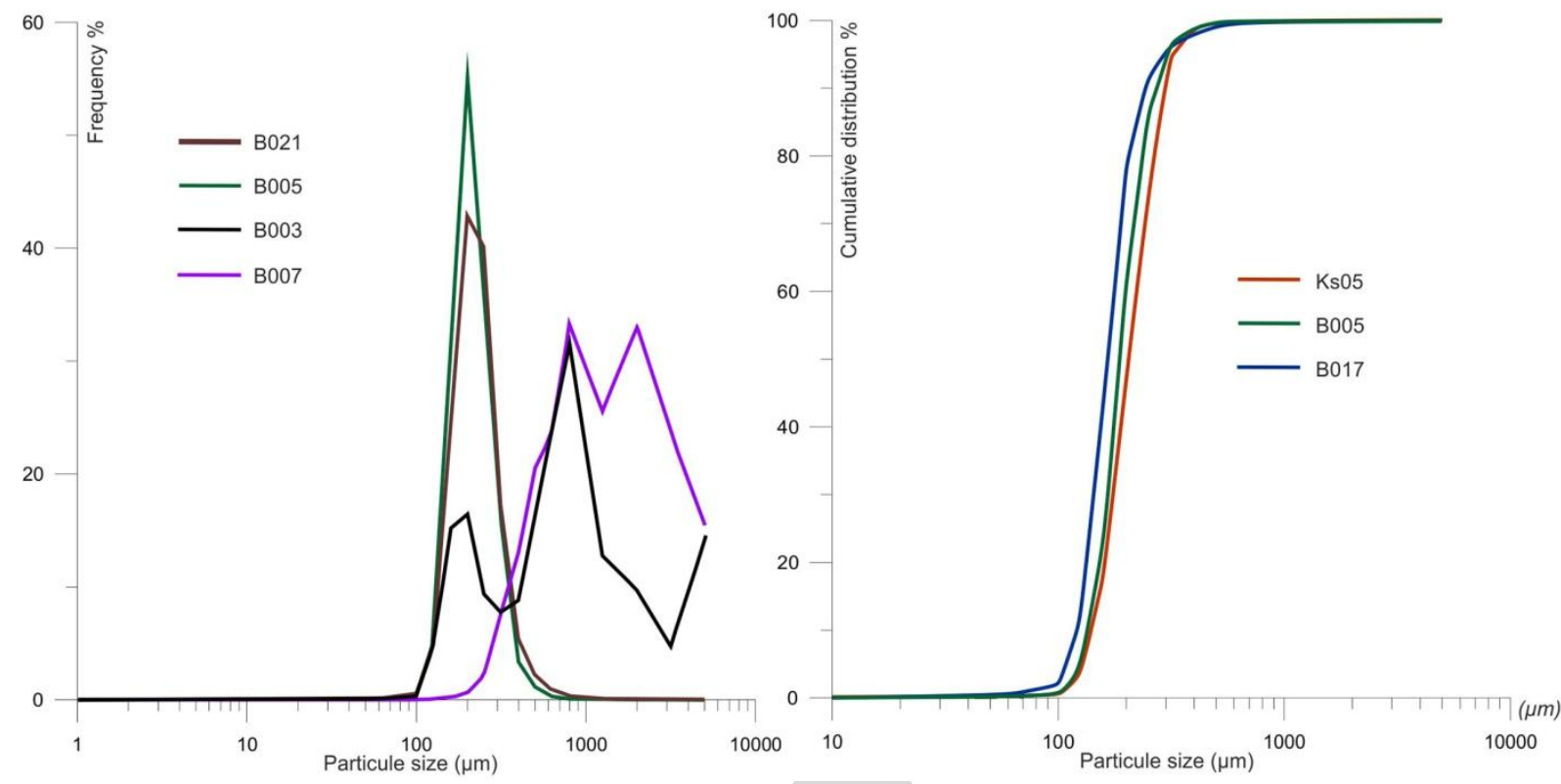

Figure 5 


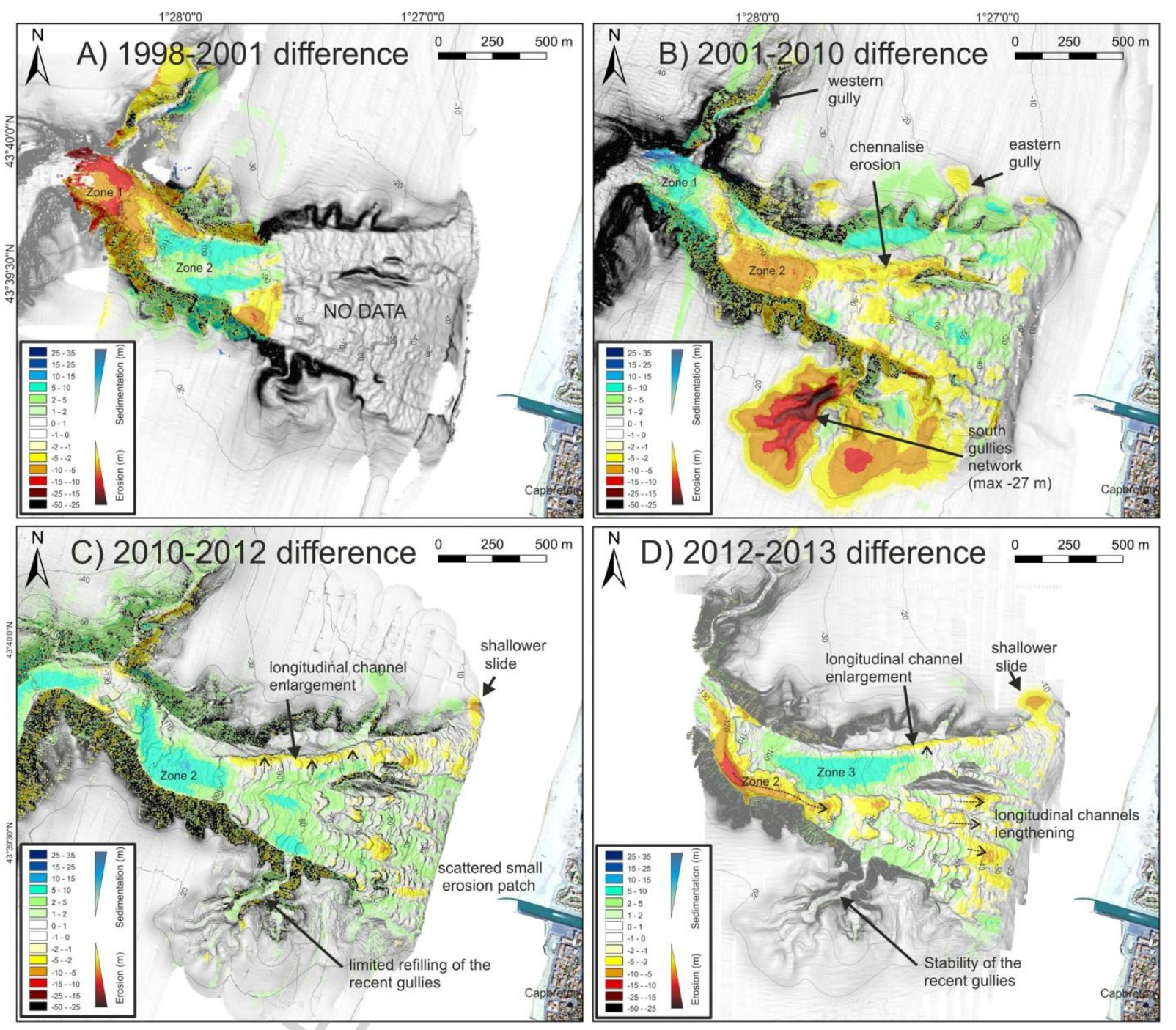

Figure 6 


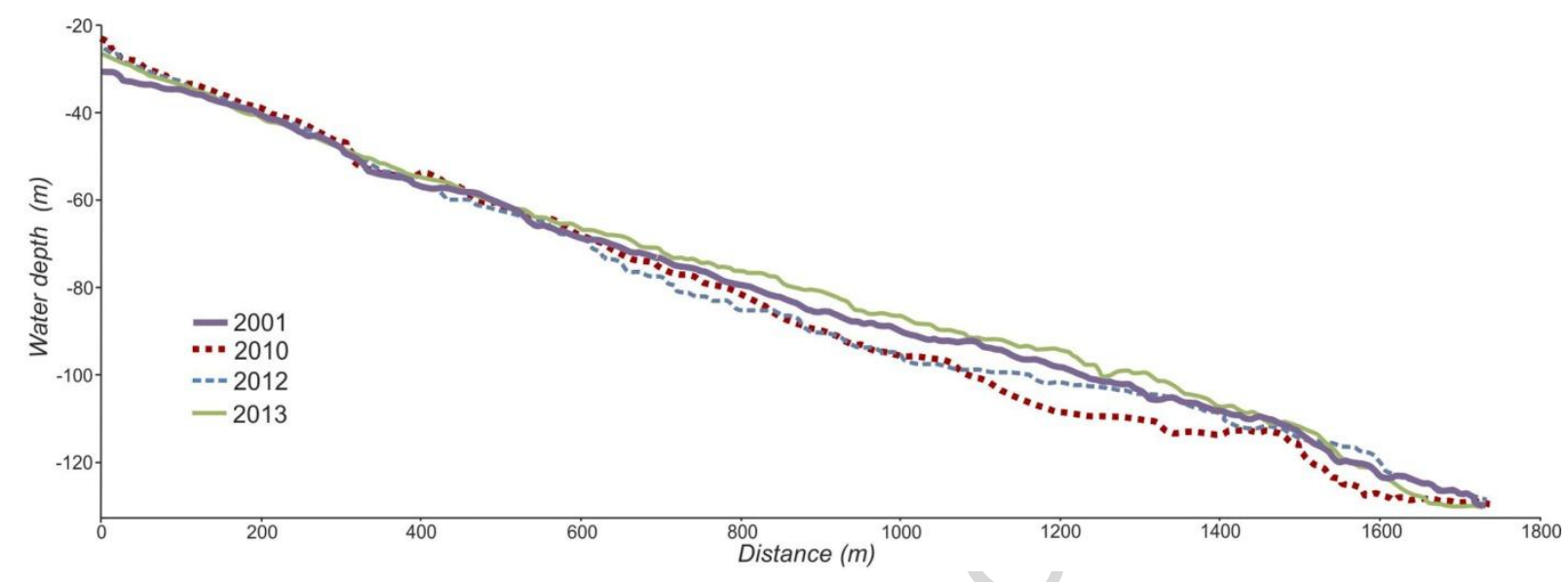

Figure 7 

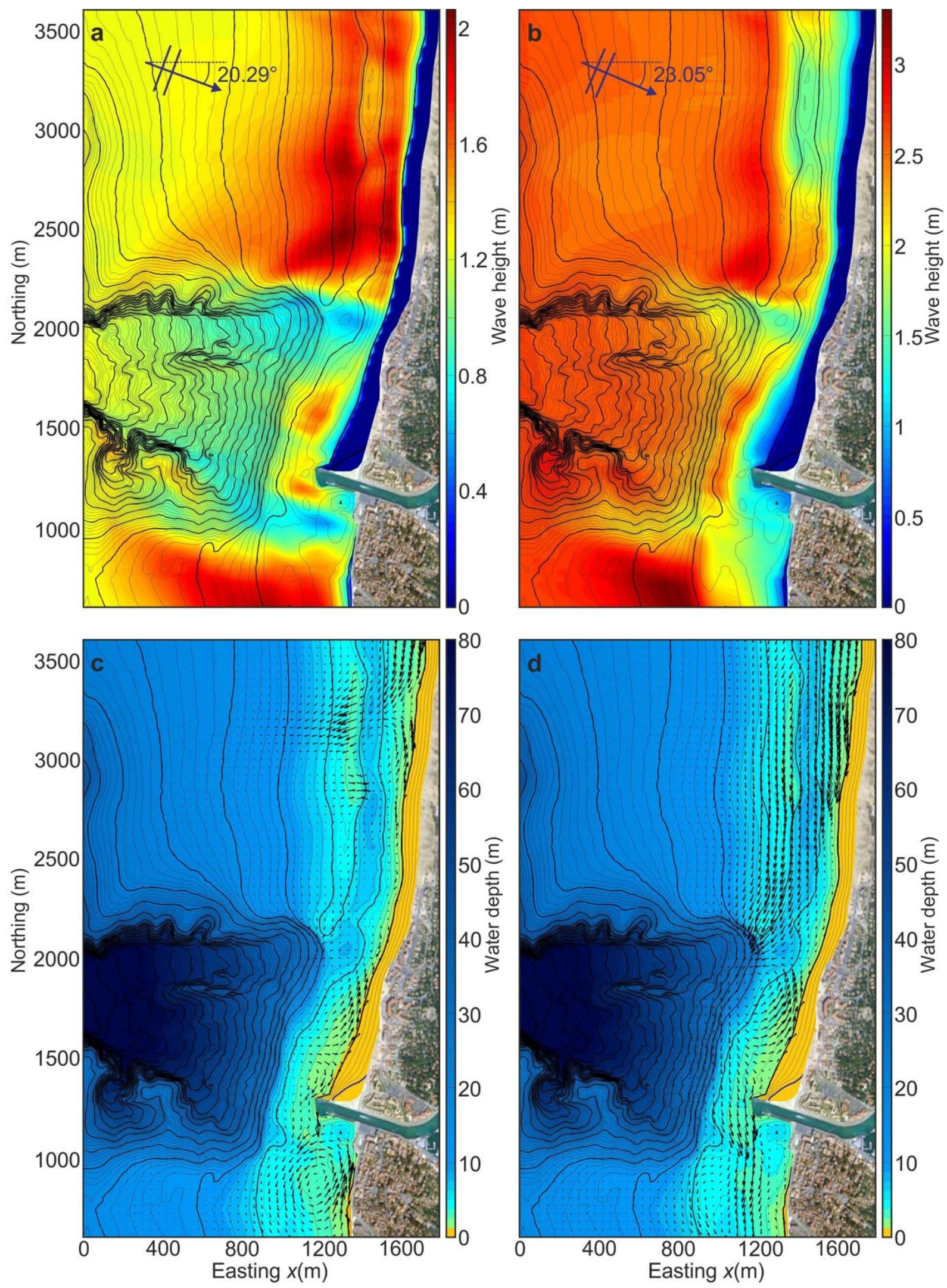

Figure 8 

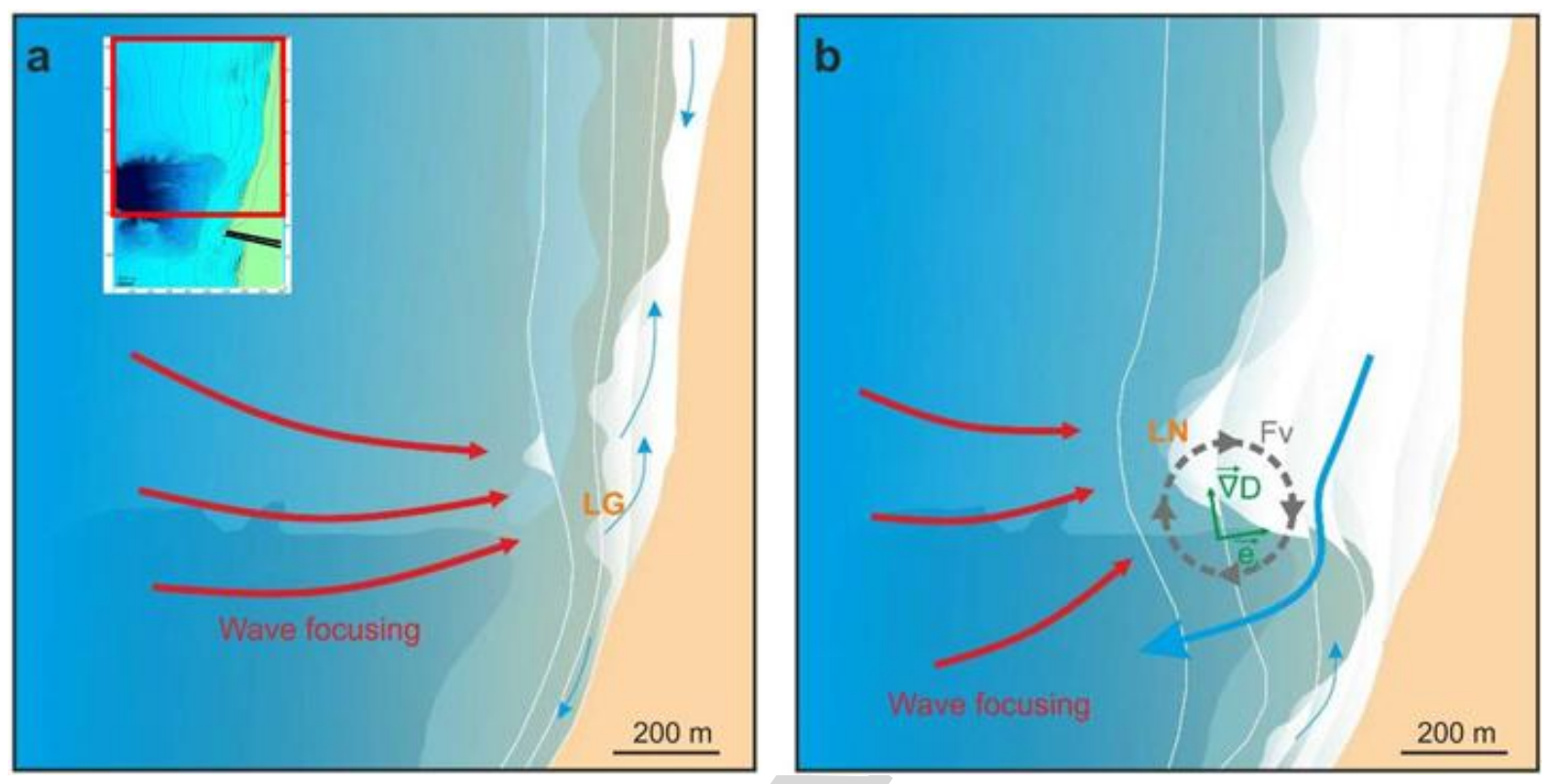

Figure 9 

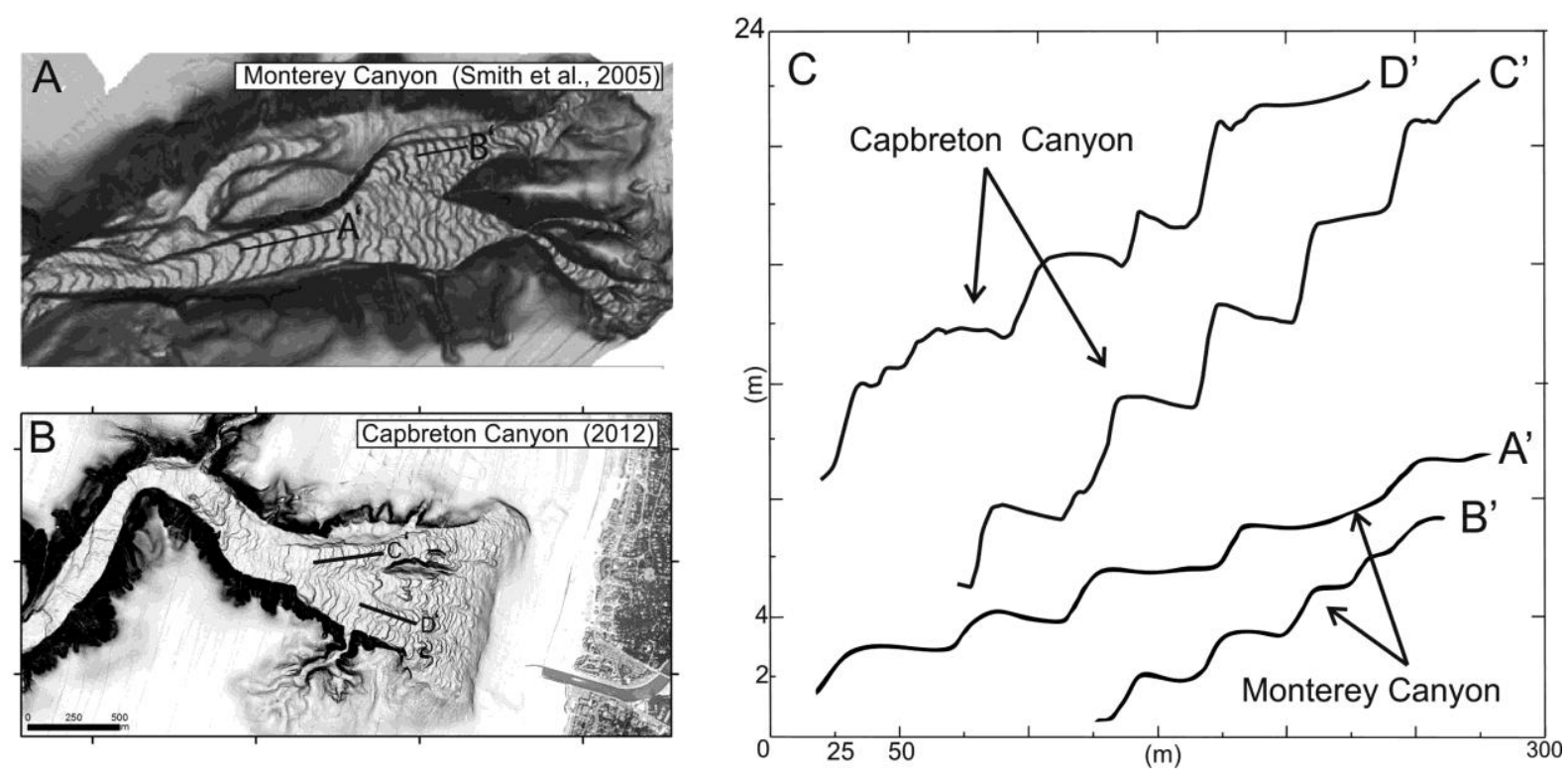

Figure 10 


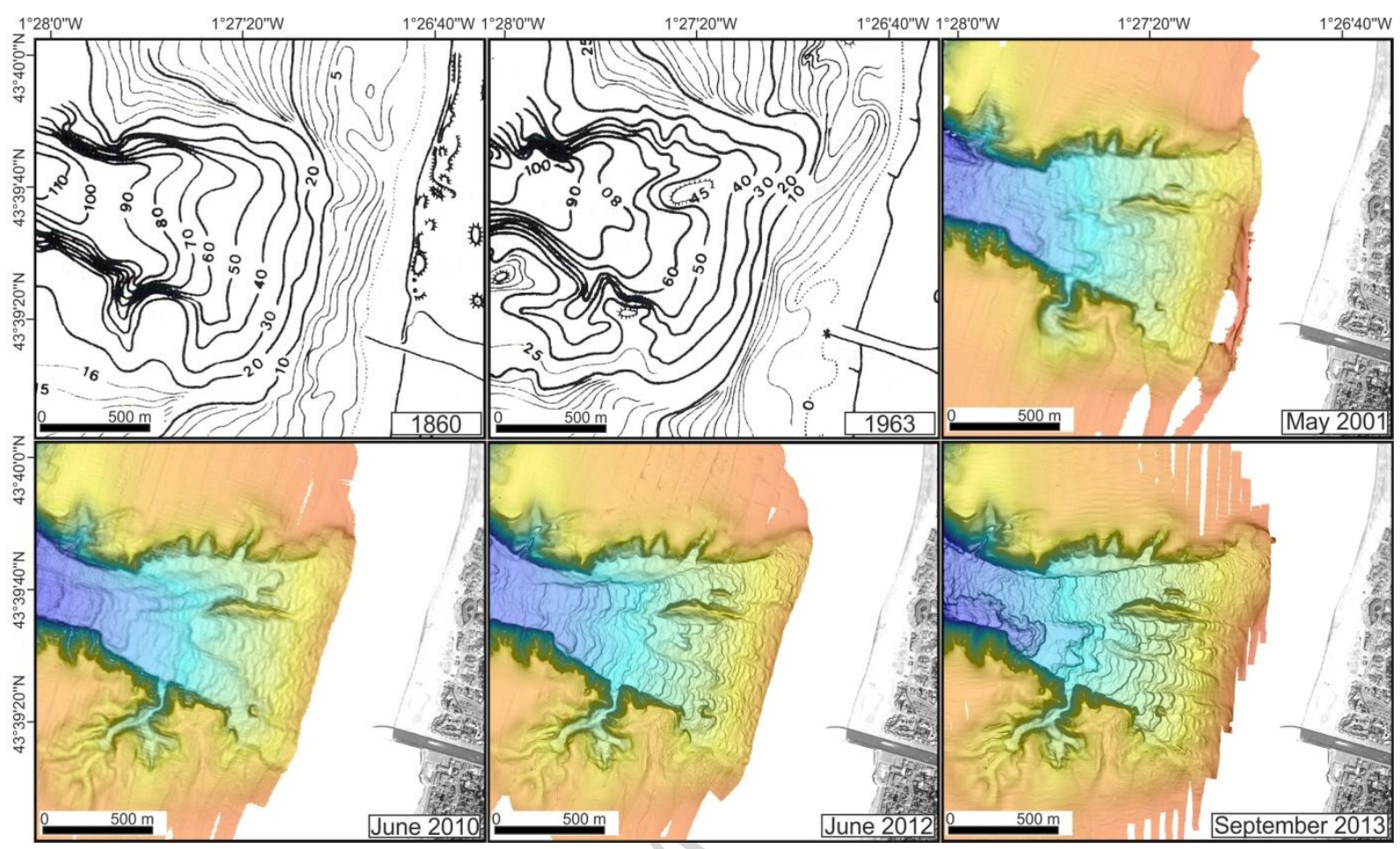

Figure 11 


\begin{tabular}{lllll}
\hline Year & Month & Name & Multibeam echo sounder & Sampling \\
\hline $\mathbf{1 9 9 8}$ & August & ITSAS 1 & EM1000, 5 m resolution & \\
$\mathbf{2 0 0 1}$ & May & ITSAS 5 & EM1000, 5 m resolution & \\
$\mathbf{2 0 0 7}$ & April-May & PROSECAN IV & & Kullenberg core \\
$\mathbf{2 0 0 9}$ & August & GOUFHEAD & Geoswath, 0.5 m resolution & \\
$\mathbf{2 0 1 0}$ & April & BERTHOIS & & Berthois cone \\
$\mathbf{2 0 1 0}$ & June & SEDYMAQ 2 & EM1000, 5 m resolution & Shipek grab \\
$\mathbf{2 0 1 2}$ & June & SEDYMAQ 3 & EM2040, 1.5 m resolution & Head of Zenkovitch core \\
$\mathbf{2 0 1 3}$ & September & PROTEUS DUNE & EM1002, 1.5 m resolution & \\
\hline
\end{tabular}

Table 1 